Crawford J \& McKee K, Hysteresis: Understanding the Housing Aspirations Gap, Sociology 52 (1) pp. 182-197. Copyright (C) The Authors 2016. Reprinted by permission of SAGE Publications.

\title{
Hysteresis: Understanding the Housing Aspirations Gap
}

\begin{abstract}
Drawing on qualitative research on housing aspirations in Scotland, the objectives of this paper are three-fold. Firstly, this paper will contextualise the subject of housing aspirations within relevant research literature and situate it within wider debates which revolve around the relationship between housing and social class. Secondly, in order to understand the implications of the research, this paper uses Bourdieu's notion of 'sociodicy' to help explain the 'social' reasons which incline people to have housing aspirations. Thirdly, the data will be analysed to understand the differences in 'aspirations' between groups, concluding that the generational differences, which correspond to the epochal changes in the economy, are more important than class differences when understanding the uneven distribution of housing outcomes and housing wealth in developed societies. This paper concludes that the Bourdieusian concept of hysteresis explains the gap between the subjective expectations of young 'professionals' and the objective chances of their realisation.
\end{abstract}

\section{Keywords}

Bourdieu, generation rent, home ownership, housing aspirations, social class.

\section{Authors}

Crawford, Joe University of St Andrews and McKee, Kim University of St Andrews

Corresponding author:

Dr Joe Crawford, Centre for Housing Research, Department of Geography and Sustainable Development, University of St Andrews, Irvine Building, North Street, St Andrews, Fife, KY16 9AL Email: jc292@st-andrews.ac.uk 


\section{Introduction}

Recent findings from a qualitative study for the Scottish Government on housing aspirations reveal a broad homology between the dominant housing tenure and the dominant form of capital accumulation (see also Harvey 2012a, 2012b and 2014). The evidence from the study suggests that there has, since the 1970s, been a strong correlation between the changing housing aspirations of the UK's citizens and the changing possibilities which arose from state involvement in extending housing market conditions to groups who had previously been excluded. Using the analysis of qualitative data from 80 in-depth interviews, this paper will both account for the 'aspirational' differences between social groups and show the extent to which these differences have not only changed over time, but have been, and continue to be, structured and shaped by the wider political economy.

This paper will advance the following thesis. Firstly, that 'aspirations' arise from the dialectical relationship between subjective desires and objective possibilities. Given that desires tend to be more or less adjusted to their chances of realisation (Bourdieu 1977, 1984, 1990, 1991, 1996, 1998, 1999, 2000) the most important aspect in this relation is not what people 'aspire' to, but what 'opportunities' exist to make these aspirations 'thinkable' and therefore 'achievable'. Secondly, despite the primacy of objective factors in determining 'aspirations', subjectivity plays an important role, insofar as the dispositions (habitus) which direct the choices, tastes and preferences of individuals, are socially structured and are therefore, like the social conditions which structure them, unequally distributed. Thirdly, our research findings suggest that the epochal changes to the political economy, the first of which extended markets to groups who had previously been excluded, has, through the shift from industrial to financialised forms of capital accumulation, reached a period characterised by 'rentier capitalism'. We, in line with economists such as Smith, Marx and Keynes (Block and Sommers 2014) define rentier capitalism as an unproductive form of 'unearned wealth' accumulation which relies upon the extraction of rent (Harvey 2014, Piketty 2014, Sayer 2015). This, it will here be argued, represents a shift from an emphasis on the mortgage market to one which prioritises the private rented housing market, a change which means that those who 
had traditionally been home owners (those groups with high levels of cultural capital yet relatively modest levels of economic capital) can now only dream of the home ownership opportunities afforded to the working classes of the 1980 s and early 90 s.

The UK, has since the 1980s, been transformed into a nation of home owners (Gurney 1999; Ronald 2008; McKee 2011). Key policies driving this forward include Thatcher's Right to Buy policy, which enabled sitting council tenants to buy their home at heavily discounted rates, and which has more recently also been extended to housing association tenants (Forrest and Murie 1988; McKee, Muir and Moore 2016); low-cost homeownership policies, such as Shared Ownership and Shared Equity schemes, which reduce the owner's stake in the property thus making a mortgage more affordable (McKee 2011); and the recent rise of Rent-to-Buy schemes (DCLG 2014) and savings account which offer favourable rates for FirstTime-Buyers (HM Treasury 2015). Whilst levels of home ownership have stagnated since the global financial crisis of 2008 (Kennett et al 2013), it nonetheless remains the largest housing tenure in the UK as well as the 'normalised' tenure of choice (McKee 2011). Although housing policy in Scotland has taken a different tact since the re-establishment of the Scottish Parliament in 1998 (McKee and Philips 2012), policies to promote homeownership are nonetheless also prevalent in Scotland, albeit co-existing alongside a more positive approach to social housing. ${ }^{1}$ This dual approach is in direct contrast to the policies of the current UK Conservative Government in Westminster, which has badged itself as the 'party of homeownership' (Conservative Party 2015: 53-54), and continues to further marginalise and stigmatise social housing in England whilst simultaneously continuing its longstanding commitment to valorising and promoting home ownership. By utilising Bourdieusian concepts in accounting for the drivers of 'aspiration', as well as the objective reality within which they arise, this paper outlines the ultimate importance of thinking about the wider context in which aspirations are shaped and come to be. 


\section{Housing, Social Class and Aspirations}

The research literature on housing and social class has, in the last half century, expanded across a number of disciplines (Allen 2007). Aspirations research has been an integral part of both health and education studies (Silver 1973, Butler and Robson 2001, 2003, Taylor 2001) since the 1970s, but the literature on housing aspirations is much less abundant. This paper seeks to advance the existing knowledge base by drawing together the three concepts; housing, social class and aspirations. A number of researchers have, either directly or indirectly, examined the relation between housing and social class through a Bourdieusian lens. McKenzie's $(2012,2013,2015)$ ethnographic work in St Anne's in Nottingham has drawn on Bourdieusian notions of 'capital' to explain the processes by which residents from stigmatised estates create meaning and 'community' in the face of external social stigmatisation. One of the most explicitly Bourdieusian scholars to tackle issues around housing and social class in the UK is Savage (Savage et al 1990, Savage et al 1995, Savage et al 2005, Savage and Bennett 2002, Savage 2005), developing a specific research agenda around housing and housing mobility and its relation to ever changing conceptualisations, representations and definitions of class (Savage et al 2013, and Savage 2015). These works, in conjunction with the various strands of research applying Bourdieusian concepts, have contributed to the construction of a highly nuanced understanding of the complex relationships which connect social space and physical space as well as the relationship between social mobility and geographical mobility, (Savage 1988, Hamnett 1984, 1987, 1989, 1994, Hamnett and Cross 1998, Raco 2009, 2013a). This has been examined from both a working class (Forrest and Murie 1988, Cole and Furbey 1994, Allen 2007, McKenzie 2012, 2013, 2015, Paton 2013, 2014), as well as a middle class perspective (Butler and Robson 2001, 2003a, 2003b, Watt 2005, Savage et al 2005, and Paton 2009). These debates have both informed, and have been informed by, research on the importance of geography in relation to aspiration (Butler and Hamnett 2011, Hamnett and Butler 2011, Paton 2014).

Raco's $(2009,2013)$ theoretical work on existential politics, however moves the focus from a specifically defined 'class-based' approach to a focus on the shift from 
expectational forms to aspirational forms of citizenship for members of all classes. For Raco, the concept of the aspirational citizen has its origins in the processes through which neoliberal policy sought to create 'the 'right' types of aspiration through the promise of performance related rewards and individual fulfilment (Raco 2013: 49). The aspirations of the UK's citizens were, according to Raco (2009, 2013), made and remade through New Labour's success in shifting 'official' discourse from a model based on 'expectational citizenship' (state as provider) to 'aspirational citizenship' (state as enabler). Raco's arguments provide a solid foundation upon which to build a theory of aspirations which transcends class boundaries, accounting for intergenerational as well as sociological factors. Our paper develops these issues further by adding an empirical dimension to Raco's theoretical work. Firstly, our data highlights the temporal nature of 'official' discourse (such as that which defines the terms of existential politics), with aspirations transformed dialectically in line with transformations in the political economy. This is evident, for example, through the fact that many middle class professionals struggle to obtain today, what working class households were readily given only a few decades ago. Secondly, these transformations tend always to cause a gap to emerge between what individuals and groups subjectively want, and the objective chances of their realisation. Borrowing a Bourdieusian term, we will call these gaps hysteresis, a key concept which we will explore later.

As we've already commented, research into housing aspirations has almost exclusively looked at the subjective preferences of individuals and has mostly neglected the objective reality which makes desires realisable, and therefore 'aspirational'. The distinction here between subjective and objective forms of reality is that the latter is characterised by the material conditions which, beyond the influence of subjective desires, render possible or impossible certain outcomes. In this case, we have noticed that most research ignores the material possibilities such as those which arise from economic conditions, employment trends, lending environments, etc., focusing instead on what people simply desire. For example, a study by Ipsos MORI (2010), which conducted over 1000 telephone interviews on the housing aspirations of people in Scotland, asked people about their subjective 
preferences, offering an account of what people wanted, desired and wished for in terms of their ideal type of housing tenure and type. There has however been some more, critically informed housing policy research commissioned. Shelter's insightful research report Home Truths (Edwards 2005) concludes that the continual push towards home ownership has, since the 1980s, driven up aspirations across all sections of society with the exception of the low waged and the no-waged who, despite state intervention to expand markets, have remained excluded. Past research has also underlined the importance of geography, with Townsend's (2006) research reporting that location was the key facet of aspirations, as houses of one type could be stigmatised in one location while exactly the same types of houses could be highly sought after in another area.

The argument we wish to advance is that the relationship between housing and social class has undergone further change, just as it did at the end of the FordistKeynesian period, when the market for housing was extended to groups who had previously been excluded. The decline in home ownership and the rise in the numbers of households now renting privately represents, we argue, a period of transition from 'neoliberal' to 'rentier' forms of capital accumulation. The argument made here suggests that the dispositions people have (such as their housing tastes and aspirations) persist long after the social conditions which shaped them have ceased to exist. This explains why many young 'professionals' with more cultural than economic capital still 'aspire' to owning their own home through a mortgage, despite the objective chances of them obtaining the large sum required for a deposit continuing to diminish. The 'aspirational gap' between what young professionals subjectively expect and the objective opportunities of their realisation can be explained using Bourdieu's $(1990,1998,2000)$ notion of hysteresis. Hysteresis is, for Bourdieu, the gap between the changing conditions of the field (in this case the field of housing) and a person's habitus, the durable yet malleable sets of dispositions which people acquire, mainly through the internalisation of their external world, as part of the process of socialisation. Our conceptual use of hysteresis is novel in both the sociological study of aspirations, and indeed in the wider field of housing studies, and this represents an important contribution to these debates. In 
[Type here]

order to adequately account for the relation between subjective expectations (habitus) and objective possibilities (field) it is however necessary to firstly understand the role of housing as a form of 'sociodicy'. 
[Type here]

\section{Housing as a Form of Sociodicy}

For Bourdieu (2000) Sociodicy is that which 'justifies' the state of society, in relation to the uneven distribution of symbolic capital (status) and negative symbolic capital (stigma). Sociodicy, in a housing context, represents the homology between a person's social position (where they are located in social space) and their geographical position (where they are located in physical space). It acts, therefore, as a vindication of class inequality (Bourdieu 1996a, 2000). Indeed, it can be argued that for Bourdieu, social space and physical space are very closely linked.

'The idea of difference is at the basis of the very notion of space, that is, a set of distinct and coexisting positions which are exterior to one another and which they are defined in relation to one another through relations of proximity, vicinity, or distance, as well as through order relations, such as above, below and between; certain properties of members of the bourgeoisie or petitbourgeoisie can, for example, be deduced from the fact that they occupy an intermediate position between two extreme positions, without their subjectively identifying themselves, either with one or the other position' (Bourdieu 1996b: 11 emphasis in the original).

Thus the ruling elites of any society have tended to live in the grandest buildings in the most desirable geographical locations (Savage 1988, Hamnett 1984, 1987, 1989, 1994, Hamnett and Cross 1998,). The most stigmatized have tended to live in the most modest dwellings, in the poorest conditions, in the 'least desirable' geographical locations. The connection between social and spatial inequality has been outlined by a number of historically seminal works such as those of Engels (1845), Booth (1901 - 1902), and Orwell (1937).

The data will now be used to not only highlight the links between subjective experience and objective reality, but to show the futility of examining each perspective in isolation from the other. In doing so we make the argument that the relationship between housing and social class changed during the 1980s and early 
1990s, a period of continued expansion of housing markets to groups who were previously excluded. The problem of 'continued compound growth forever', as Harvey (2014) points out, is one of sustainability on a number of fronts. The banking crisis of 2008, caused by the extension of housing markets to US citizens, many of whom had no formal employment prospects and less chance of paying back the sums lent in mortgage loans, has, since the 'credit crunch', acted to promote rentier forms of capital accumulation around the world (Harvey 2014, Piketty 2014, Sayer 2015). This has resulted in a new relationship between housing and social class as sections of the 'middle classes' with a disproportionate volume and structure of cultural capital, a group which Watt (2005) calls 'marginal professionals', can today only dream of the homeownership opportunities which were readily available to the working classes during the period of transition from an industrial to a financially based economy. Hysteresis, we argue, represents a novel conceptual lens by which to advance this argument, and draw attention to the changing relationship between housing and class.

\section{Research Design}

Against this backdrop our research was commissioned to explore housing aspirations in a Scottish context. The paper utilises the data from 80 in-depth semistructured interviews with people in Scotland who participated in (funded research details to follow after review). A two pronged approach to recruitment was adopted (for further details, see McKee, Moore and Crawford 2015):

- Local Authority case studies: participants were recruited from five local authority case study areas: Aberdeen City, Argyll and Bute, Perth and Kinross, Renfrewshire and the Scottish Borders $(n=35)$. The case studies were selected to include a mix of rural and urban areas, and of different local housing markets and tenure structures. The case study aspect of the research design was important to understand how aspirations are mediated (or not) by geography.

- Scotland wide: 500 letters were sent to past respondents of the national Scottish House Condition Survey, inviting people to take part; we received a 
response rate of 6 percent $(n=30)$. This was supplemented by further recruitment through social media and our network of gatekeeper organisations $(n=15)$. The aim here was to widen participation beyond the case studies.

Efforts were made to include diversity within the sample in relation to housing tenure, age, gender, ethnicity and disability (for full details of the sample see the project report, McKee, Moore and Crawford 2015). The semi-structured interviews were mostly conducted by telephone, although there were two focus groups $(n=7)$ and five face-to-face interviews to accommodate participant's preferences. The aims of the interviews were to seek information relating to people's past, present and future housing aspirations. The qualitative data was imported into the qualitative analysis software NVivo 10 and then analysed thematically. In line with the principles of Constructivist Grounded Theory (CGT) (Charmaz 2014). CGT builds on the original approach of Glaser and Strauss (1967), but is underpinned by a much more relativist epistemology which emphasizes the positionality of the researcher and the socially constructed nature of knowledge. Theories are not out there waiting to be discovered, rather interpretation is always partial and incomplete, and shaped by the researcher's experience in the field.

\section{Understanding why 'aspirations' differ between groups}

Thematic analysis of our qualitative data showed that the sample could be grouped into four broad categories, which corresponded to the four distinct eras of capital accumulation. The relationship between these four categories and the economic epochs from which they have issued, is a dialectical one which takes account of the objective (material and economic) conditions within which people find themselves and the subjective perspectives (the aspirations, desires and wishes) which arise from these conditions. This dialectical relationship accounts for the primacy of objective factors in shaping subjectivities while at the same time avoiding the pitfalls of economic determinism through an overly 'structuralist' explanation. The categories below are broad generalisations which account for the strong connection between economic forms and the forms of housing provision, tenure being one 
dimension. This method allows for housing and tenural trends to be linked to their wider economic drivers, accounting for the shifts from private renting in the prewelfare epoch, to social housing in the Fordist-Keynesian epoch, to home ownership in the financialised epoch and then back to private renting in the current 'rentier' epoch. These are detailed as follows;

- Social Tenants $(n=20)$ : industrial era of capital accumulation, 1950s - 1979

- Lucky Owners ${ }^{2}(n=24)$ : (the extension of markets to those previously excluded, 1979 - 2000)

- Housing Bubble Buyers ( $n=17$ ): period of unregulated asset inflation, 2000 2008)

- Generation Rent $(n=19)$ : the return of rentier capitalism and never-ending austerity, 2008 - present

The broad homology between the dominant tenure and the dominant form of capital accumulation in any given epoch was one of the most significant findings to emerge from our research into housing aspirations. There is, evidently, a very strong link between the extension of markets, to those groups who had previously been excluded from home ownership, and the rise in the number of people who clearly 'developed' aspirations to become home owners. One of the other significant findings suggests that although 'class' is clearly an important determinant factor which influences housing possibilities and expectations, political economy is also important. The transition from an economy based on industry and production to one of finance and consumption gave relatively low waged working class households the ability to purchase their house at a considerable discount. A combination of banking sector liberalization and the introduction of policies designed to extend markets such as the right to buy your council house (RTB) allowed many working class households to enter into economic practices (mortgage holding and home owning) which were previously out of reach in both subjective and objective terms. The extension of housing markets made it easier for more affluent working class and middle class households to set a generational trend towards home ownership, a trend which, 
having lasted some 30 to 40 years, may be nearing its end with the steep rise in asset values pushing homeownership beyond groups who lack the economic capital and/or whose parents cannot provide the sums required for a mortgage deposit (McKee 2012).

For large numbers of households of a certain age who possessed a greater volume and structure of economic (and cultural) capital, getting a mortgage has, since around the 1960s, tended to be the 'natural' thing to do, as this participant recounted;

'We paid off our mortgage in 1984. I married in 1967, got straight onto the property ladder, which is just what you did in those days. There wasn't a rising market then, so I left London in 1984 in profit and moved up here. My house isn't worth £1 million but there are houses a couple hundred yards from here that would be worth that. I would value the house we are in just now about $£ 700,000$. It is a long way from the $£ 600$ that we paid for our first house in the 1960s!' (Female, home owner, 65+ age group).

The steady increase in the numbers of people who bought a home in the post-war period had the effect of normalising home ownership (Gurney 1999, Rowlands and Gurney 2000; McKee 2011). 'Normal' or more accurately, 'normalised' forms of behaviour, which are socially mediated and objectively structured through the extension of markets to those previously excluded, create aspirations within groups who had never before thought about home ownership, because they previously never thought they would be able to 'afford' home ownership. Clearly, there exists (or arguably there has existed) a significant difference between what dominant and dominated groups can aspire to, or indeed expect. These differences are determined by their relative distance from economic necessity (Bourdieu 1990, 1991, 1994, 2000), holding the key to what can, and what cannot be 'imagined'.

Focusing on the 'generational' differences contained in the data highlights the 'aspirational gap' between those born at divergent economic epochs. The following excerpt shows that in the transition period from an industrial to a financial economic 
base, employees (those who populated the group Generation Lucky Owners) could 'work hard', save up and access the property market in ways that contemporary workers (those young professionals from Generation Rent) simply cannot do:

'I didn't have a fantastic job or a fantastic amount of money. I worked hard and saved enough for a deposit with my wife. My wife was a radiographer, I was a farm manager. Which is not the best of paid jobs but I worked very hard and put a lot of effort in. I knew what I wanted. I wanted a house of my own. So I didn't smoke, and various things like that. I managed to get the deposit that I needed and a lot of my friends did as well' (Male, home owner, $65+$ age group).

We concur that this aspect of the data accords with the bulk of the research literature which has, since the 1970s, dealt with the connections between housing and social class. We would, however, argue that the current situation, particularly that experienced by young professionals who have a disproportionate volume of cultural capital (in our sample, school teachers, architects and researchers) is divergent from the scholarly doxa which divides working class and middle class households according to their ability to acquire housing of a certain tenure, in a particular location:

'But it is sad. My generation were lucky because my husband had worked for 32 years for the same company, at that point you got your pension, it was all just done for you as it were, and we are the last generation I think that's going to happen to, because the next generation are having to make provision for their own pension and if you are in a position like my son's in where you've never had a really highly paid job and he's on his own so if he can't work then that's it, you know' (Female, home owner, 65+ age group).

The generational difference was at its starkest in the data when comparing like-withlike occupations in both a tenural and locational context. School teachers from the Generation Lucky Owner group had paid off mortgages for homes in locations of their own choosing, claiming to have met their housing aspirations. School teachers from the Generation Rent cohort spoke of feeling 'trapped' in PRS accommodation, 
unable to meet their aspirations in relation to both tenure and location as one participant comments:

Interviewer: 'I have to ask you the question: Do you not think it's shocking that someone who is working as a school teacher in the UK is saying that they don't know if they can ever afford a house in a place like Glasgow?'

Interviewee: 'Of course it is, yes. Obviously, it's a good job and it's a professional job, but on my own, I could never afford that. I could just about afford to rent a flat here myself, but that's about it. But even with two wages, I don't know because it's very expensive around here. I do often wonder who can afford houses in the south side. What are they doing for a living? I think they must be business owners. I don't see me doing it, to be honest' (Female, private renter, $25-34$ age group).

The next excerpt is from a conversation with a student architect whose wife was a school teacher. They lived in the PRS with their toddler son as they could not afford a mortgage. They were hopeful of being able to afford a mortgage in the future with two professional wages combined. They lived in a place (a medium sized town) where house prices were much less than they were in the larger cities:

'We have some money for a deposit but nowhere near the amount we would need, even if it is $5 \%$ for what we would want to buy, we don't have that. But I think all going well, when I qualify... my wife has got a good job - she is a professional - two of us put together should be able to afford a mortgage' (Male, private renter, 25 - 34 age group).

The next example, taken from an interview with a school teacher whose partner is a police officer, demonstrates the multiple barriers 'Generation Rent' have to overcome to realise home ownership in the current epoch. The Help-to-Buy scheme mentioned here is a policy measure aimed at assisting households to access the mortgage market. Here the interviewee, who bought their home through this scheme, 
lists the significant barriers to home ownership which she and her partner had to overcome in realising their housing aspirations.

'I think if we had not been able to move in with Stephen's parents, I think we would probably be in rented accommodation which is much much smaller and would probably be renting out my property. I was in deficit when I sold my flat so we had to take a big chunk of my savings out to get rid of my flat because you can't access help-to-buy if you've already got another property. So, yes I think we were extremely lucky that we had Stephen's mum and dad who were very accommodating with us, especially because we've got the wee one as well... they were putting a roof over our heads and we were very lucky they were able to do that for us. We were very lucky and it's got us to where we are now and we appreciate our house and our situation so much more now and we enjoy our house much more because we've had to go through that, living in someone else's house' (Female, mortgage holder, 25 - 34 age group).

The vast majority of young professionals who lived in the PRS, intimated a preference to either own their own home or to rent from a social landlord in situations where they thought homeownership to be beyond their reach, but there was one exception. The following example comes from perhaps the only interviewee (out of 19 in the PRS) who looked upon renting as a favourable option given the current financial climate. This young man, an interior designer, felt that renting afforded him the sort of 'lifestyle' which suited his 'social position':

'Yes because I think it just gives you more sort of upwardly mobile flexibility. I can rent something far nicer than I could afford to buy. Okay it's not mine but I think it depends on what I can afford. I do not think I can afford a house that suits my lifestyle so it has to be a flat' (Male, private renter, 25 - 34 age group).

The growth of the PRS over the last 15 years in the UK means it is now home to a diversity of households types: no longer simply the mobile young professionals and 
students it has traditionally been associated with (see, Hoolachan et al 2016). More research is however needed to understand the diversity of these experiences and how renting privately impacts on people's identity and well-being.

Nonetheless our data showed that there was widespread recognition of the generational differences, with Lucky Owners showing a great deal of sympathy for those in Generation Rent:

'I think it is a problem for young people ... I mean our first house I think cost about $£ 3,000$ and we got help from an aunt, she gave us a down payment which was very good, we paid that but now I don't know... it's very difficult. I don't see how unless you've got relatives that are willing to... or the bank... I don't see the bank lending, so it's all down to relatives. Who has that kind of money to spare?' (Male, home owner, 65+)

The next interviewee showed an acute awareness of the current economic difficulties facing young people in both an employment and a housing capacity (see also, Hoolachan et al 2016). There were a number of interviewees who described how they have helped their children financially. Of those who had, a large percentage had used the term 'bank of mum and dad' when talking about intergenerational support (see also Heath and Calvert 2013). These were almost exclusively from the Generation Lucky Owner cohort, which illustrates the fact that although there is discontinuity between generations, a link still exists insofar as those whose parents were able to take advantage of low cost home ownership during the 1980s were in a better position to help their children with a deposit. The intersectionality between age and class is an important one that merits further research and exploration:

'I am putting money away for my kids so I can give my kids a deposit for a house. It's not exactly $£ 50,000$ but you know. I would like my children to end up in home ownership because I still think it's the best tenure. I think it has its downsides and I don't think it's the Holy Grail but what I think is the alternative isn't that good because they are not going to get into social housing and I 
don't believe in the private rented sector' (Female, home owner, 45 - 54 age group).

Watt's (2005) research highlights the difference between what he calls the 'metropolitan new middle classes' (managerial professionals with a higher volume of economic than cultural capital) and 'marginal professionals' (those working in the creative and welfare professions who have a disproportionately higher volume of cultural capital) with regard to housing. The affordability of living in council housing in Camden as well as the centrality of the location meant that 'marginal professionals' could (at least in the early 2000s) pursue their career objectives, a luxury which seems to be out of reach for our respondents who also had high levels of cultural capital (school teachers, architects, academics and third sector managers) but no financial means by which to purchase a property in the current market. Our research corresponds with Watt's (2005) to the extent that those interviewed who do have high levels of cultural capital, but 'do not have affluent middle-class parents who can subsidise metropolitan homeownership' (Watt 2005: 379) are doubly disadvantaged. They are not only disadvantaged by the limitations of where they have to reside but they also lose out financially as asset values continue to inflate, widening the housing wealth inequality gap between those who own and those who rent their homes (McKee 2012).

Acknowledging the limits of our sample, an assertion can nonetheless be made regarding recent changes in the relations between objective possibilities and the subjective preferences from which they arise. Other than one interviewee who claimed to be happy in the PRS, it would appear that the tenure in Scotland is predominated by two types of tenant: those who want to own but cannot afford the deposit for a mortgage and, less evidently, those who want to rent from a social landlord but cannot access social housing due to extreme pressures on supply. We also believe that, as the possibilities of home ownership diminish for many, there may be an even greater demand for social rented housing in the future as young professionals lacking the economic capital required for a deposit may resent having to rent privately. The data showed that many in the PRS saw rent in largely negative 
terms referring to payment as 'money down the drain', or 'paying off some else's mortgage' - a finding reverberated by previous research (Gurney 1999). Other research has also highlighted the difficulties of making a 'home' in the PRS (McKee and Hoolachan 2015) - and indeed this has been one of the drivers behind recent Scottish Government reforms to private sector tenancies in Scotland. ${ }^{3}$

We believe that our arguments add further nuance to the sociological understanding of the relationship between housing and social class (Savage 1988, Hamnett 1984, 1987, 1989, 1994, Hamnett and Cross 1998, Butler and Robson 2001, 2003a, 2003b, Allen 2007, Paton 2009, 2013, 2014). The cultural middle classes (those with high levels of educational and creative capital but little financial resources), it seems, are in something of a unique position in the current epoch. For the first time since the early period of the post-war settlement, the cultural middle classes, the school teachers, academics, architects as well as public officials and senior third sector managers are struggling to realise the 'aspiration' of home ownership.

\section{Conclusion}

Our qualitative data highlights the extent to which the coupling of material conditions and government policy, under the influence of whatever form of capital accumulation is dominant at any particular epoch, determines the aspirational character of individuals in relation to housing. State involvement not only creates markets (Wacquant 2012, Block and Sommers 2014), but also the market conditions which, in the case of housing, create opportunities for people by extending markets from which they had previously been excluded. Given that housing is such an important form of sociodicy, it is understandable why people would want to aspire to have a house which contains within it as much 'symbolic importance' and therefore as much 'meaning', as possible, as this is not only a source of status, but is an important form of justification. 
The 'apparent' injustice here is that 'access' (at least historically) to housing, just like access to employment opportunities and social networks, is largely dependent upon a person's location in social space, which is dependent on the entirely unequal distribution of capital which defines its location. Those who are shorn of both economic and cultural capital lack the ability to aspire to the things which groups with high levels of economic capital can aspire to. For those middle class professional groups with more cultural than economic capital, home ownership is becoming increasingly difficult to achieve without the financial assistance of parents or other family members. What the data from this research suggests is that the transition from industrial to financial and then more recently to rentier forms of capital accumulation have had a profound effect on the relation between the dominating dominant (those with higher levels of economic capital) and the dominated dominant (professionals who possess higher levels of cultural capital in the form of skills and qualifications). It would seem that the return to rentier capitalism has diminished the 'social standing' of those who were traditionally seen as being culturally important (teachers, academics, architects and those involved in the arts), while simultaneously augmenting the power of economic groups (managers, accountants, property investors, and speculators).

In understanding the relation between housing and social class, the contribution this paper makes to current debates has three interconnected dimensions. Firstly, understanding the link between the epochal changes in economic conditions (from production to consumption) and the extension of housing markets to those previously excluded from home ownership is an important aspect of understanding tenure change in advanced capitalist countries. Secondly, it is important to acknowledge the primacy of the specific form of capital accumulation which is dominant at each specific period, in order to account for the changing relations between subjective expectations (habitus) and objective possibilities (field). Thirdly, it seems that there is something of an 'aspirational gap' opening up, which emerges from the lag between changing economic conditions (i.e. the return of rentier capitalism) and the 'economic' expectations of those groups who had, as a result of an intergenerational tradition of home ownership, have come to 'expect' certain outcomes even after the 
material conditions from which they arose have long ceased to exist. This intersectionality between age and class is significant, and an area that merits further investigation. Moreover, these conceptual insights advance our existing understanding of housing aspirations in broader terms, highlighting the dynamic relationship between the subjective and objective in an empirically grounded and theoretically sensitive way.

This paper will not make any policy recommendations. What we do wish to emphasise, however, is the possibility that the scholarly doxa which has underpinned much academic research since the 1970s with regard to housing and social class, might soon require some form of re-evaluation as further epochal changes to the political economy render as obsolete older patterns of housing consumption. If, as our research findings suggest, the market contracts to allow access only to those with the very highest volume and structure of economic capital, then definitions of social class in relation to housing will need to be modified accordingly if an accurate assessment of the link between social and physical space can be adequately made. What the data from this research strongly suggests is that the dominance of rentier capitalism in the current period places enormous pressure on households hoping to one day obtain a mortgage, as the demand for larger deposits and rising house prices in certain areas increases with time.

Hysteresis, the gap between subjective expectations, and objective possibilities which arises from the increasing gap between habitus (dispositions towards housing) and field (the current housing market) will undoubtedly result in growing disappointment for those increasingly unable to realise their dream of home ownership. Our research suggests that those unable to access 'bank of mum and dad' (Heath and Calvert 2013) will have the choice of either private renting or staying at home for longer. Returning to a Bourdieusian perspective these aspirations will, over time, become adjusted to the objective chances of their realisation. This 'compromise', as Bourdieu and Wacquant (1992) point out, carries with it a series of political consequences as witnessed in France in 1968 when student protests escalated to national strikes and civil unrest across the country. The cultural middle 
classes, feeling cheated out of their traditional material and symbolic entitlements by the rise of the economic middle classes, formed a political alliance, as they often do in times of crisis (Bourdieu and Wacquant 1992) with the working classes, a movement which would have lasting effects on the French economic and political landscape. The extent to which Generation Rent will have a political impact on the cultural middle classes of the UK remains to be seen. A Bourdieusian conclusion might suggest that it all depends upon the ability of 'young professionals' to adjust their housing aspirations accordingly. We conclude that given the cultural importance of housing as a form of 'sociodicy', this is far from guaranteed and thus presents an important insight into the uncertain future regarding not only relations between housing and social class, but the wider political order embodied by the divisions between economic and cultural fields of power.

\section{Acknowledgements}

Thank you to the two anonymous reviewers for their helpful comments. This research: 'Understanding the Housing Aspirations of People in Scotland' was funded by the Scottish Government.

\section{End-notes}

$1 \mathrm{It}$ is beyond the scope of this paper to give a detailed account of the policy differences between Scotland and England in the context of devolved policy-making in the UK. For a fuller discussion of these nuances as they relate to the argument expressed here, please see McKee and Phillips 2012, McKee et al 2016.

2 The use of the word 'Lucky' here is to reflect the general consensus among interviewees from this epoch, most of whom, when comparing their situation with the difficulties young people today face trying to get on the property ladder consider themselves to have been 'lucky'.

3 The Private Housing (Tenancies) (Scotland) Act 2016 proposes a number of reforms to private rented sector tenancies, including greater security of tenure: http://www.legislation.gov.uk/asp/2016/19/contents/enacted 
[Type here]

\section{References}

Allen C (2007) Housing market Renewal and Social Class. London: Routledge

Block F, Sommers MR (2014) The Power of Market Fundamentalism. Karl Polanyi's Critique. Cambridge MA: Harvard University Press.

Booth C (1902-1903) Life and Labour of the People in London (17 volumes). London: MacMillan.

Bourdieu P (1977) Outline of a Theory of Practice. Cambridge: Cambridge University Press.

Bourdieu P (1984) Distinction. London: Routledge.

Bourdieu P (1990) The Logic of Practice. Cambridge: Polity Press.

Bourdieu P (1991) Language and Symbolic Power. Cambridge: Polity Press.

Bourdieu P (1996a) The State Nobility. Cambridge: Polity Press.

Bourdieu P (1996b) Physical Space, Social Space, and Habitus. Rapport 10. Institutt for Sociologi: Universitetet I Oslo.

Bourdieu P (1998) Practical Reason. On the Theory of Action. Cambridge: Polity

Bourdieu P (2000) Pascallian Meditations. London: Polity Press.

Bourdieu P (2005) Social Structures of the Economy. Cambridge: Polity

Bourdieu P and Wacquant L (1992) An Invitation to Reflexive Sociology. London: Polity.

Butler T and Robson G (2001) Social Capital, Gentrification and Neighbourhood Change in London: a comparison of three south London neighbourhoods. Urban Studies 38(1): 2145 - 2162.

Butler T and Robson G (2003a) Negotiating Their Way In: The Middle Classes, Gentrification and the Deployment of Capital in a Globalising Metropolis. Urban Studies 40(9): 1791 - 1809.

Butler T and Robson G (2003b) Plotting the Middle Classes: Gentrification and Circuits of Education in London. Housing Studies 18(1): 5 - 28

Butler T and Hamnett C (2011) Ethnicity Class and Aspiration, Understanding London's East End. Bristol: Policy Press. 
[Type here]

Charmaz K (2014) Constructing Grounded Theory. $2^{\text {nd }}$ edition. London: Sage.

Cole I and Furbey R (1994) The Eclipse of Council Housing. London: Routledge.

Communities and Local Government (2008) Housing Choices and Aspirations of Older People Research from the New Horizons Programme.

https://www.york.ac.uk/media/chp/documents/2008/newhorizonsolderpeople.pdf (accessed 3 May 2015)

Conservative Party Manifesto (2015) https://s3-eu-west-

1.amazonaws.com/manifesto2015/ConservativeManifesto2015.pdf (accessed 16 August 2015)

Department of Communities and Local Government (2014) New 'Rent to Buy' scheme to help young people save and move up the housing ladder:

https://www.gov.uk/government/news/new-rent-to-buy-scheme-to-help-youngpeople-save-and-move-up-housing-ladder (accessed 20 August 2015)

Edwards $L$ (2005) Shelter Home Truths. The reality behind our housing aspirations. ISBN 1-903595-49-5

Engels F (2009 [1845]) The Condition of the Working Class in England. London: Penguin.

Forrest R and Murie A (1988) Selling the Welfare State: the privatisation of public housing. Routledge: London.

Gurney C (1999) Pride and Prejudice: discourses of normalisation in public and private accounts of home ownership', Housing Studies 14(2): 163-183.

Hamnett C (1984) Housing the two nations: sociotenurial polarization in England and Wales, 1961-81. Urban Studies 43: 389-405.

Hamnett C (1987) A tale of two cities: socio-tenurial polarization in London and the South East, 1966-81. Environment and Planning A 19: 537-56.

Hamnett C (1989) Socio-tenurial polarization in London and the South-East: a reply to Berge's comments. Environment and Planning A 21: 545-8.

Hamnett C (1994) Social polarization, economic restructuring and welfare state regimes. Urban Studies. 33(8): 1047-50.

Hamnett C and Cross, D (1998) Social polarization and inequality in London: the earnings evidence 1978-95, Environment and Planning A, 16(6): 659-80.

Hamnett C and Butler, T (2011) Geography matters: the role distance plays in reproducing educational inequality in East London. Transactions of the Institute of British Geographers 36(4) 479 - 500 
Harvey D (2012a) 'Ponzi Scheme Capitalism: An Interview with David Harvey by Steffen Böhm'. http://review31.co.uk/interview/view/16/ponzi-scheme-capitalism-aninterview-with-david-harvey (accessed 14 July 2015)

Harvey D (2012b) Rebel Cities: From the Right to the City to the Urban Revolution. London: Verso

Harvey D (2014) The Seventeen Contradictions and the End of Capitalism. London: Profile Books

Heath E and Calvert S (2013) Gifts, Loans and Intergenerational Support for Young Adults. Sociology 47(6): $1120-1135$

Her Majesty's Treasury (2015) Help to Buy: ISA- scheme outline:

https://www.gov.uk/government/uploads/system/uploads/attachment data/file/41389 9/Help to Buy ISA Guidance.pdf (accessed 9 June)

Hoolachan JE, McKee K, Moore T and Soaita AM (2016) 'Generation Rent' and the Ability to 'Settle Down': economic and geographic variation in young people's housing transitions. Journal of Youth Studies (Online Early):

10.1080/13676261.2016.1184241

Ipsos MORI (2010) Housing Aspirations in Scotland. https://www.ipsosmori.com/researchpublications/researcharchive/poll.aspx?oltemld=2691 (accessed 20 October 2015)

Kennett P, Forrest R and Marsh A. (2013) The Global Economic Crisis and the Reshaping of Housing Opportunities. Housing Theory and Society special issue: $30(1): 10-28$

McKee K (2011) Challenging the Norm? The 'Ethopolitics' of Low Cost Homeownership in Scotland. Urban Studies 48(16):3399-3413

McKee K. (2012) Young People, Homeownership and Future Welfare' Housing Studies 27 (6): 853-862

McKee K and Phillips D (2012) Social Housing and Homelessness Policies: reconciling social justice and social mix pp 227-242, in G Mooney and G Scott (eds) Social Justice and Social Policy in Scotland. Bristol: Policy Press

McKee K. and Hoolachan J. (2015) Housing Generation Rent: what are the challenges facing Housing Policy in Scotland? St Andrews: Centre for Housing Research, University of St Andrews.

McKee K, Moore T and Crawford J (2015) Understanding the Housing Aspirations of People in Scotland. Social Research, Scottish Government, Edinburgh 
McKee K, Muir J and Moore T (2016) Housing Policy in the UK: the importance of spatial nuance. Housing Studies (Online Early):

http://www.tandfonline.com/doi/full/10.1080/02673037.2016.1181722

McKenzie L (2012) A narrative from the inside, studying St Anns in Nottingham: belonging, continuity and change. Sociological Review. 60(3): $457-475$.

McKenzie L (2013) Narratives from a Nottingham Council Estate: astory of white working-class mothers with mixed race children. Ethnic and Racial Studies. 36(8): $1342-1358$

McKenzie L (2015) Getting By. Estates, Class and Culture in Austerity Britain. Bristol: Policy Press

Orwell G (2001 [1937]) The Road to Wigan Pier. London: Penguin.

Paton K (2009) Probing the symptomatic silences of middle-class settlement: A case study of gentrification processes in Glasgow. City 13, 4.

Paton K (2013) Exploring housing and class in hard times: working-class place attachment and "elective fixity" Special Issue: Housing in Hard Times, Housing Theory and Society 30(1): 84 -100

Paton K (2014) Gentrification: A Working-Class Perspective. London: Ashgate.

Piketty T (2014) Capital in the 21st Century, Cambridge: Harvard University Press.

Raco M (2009) From expectations to aspirations: State modernisation, urban policy, and the existential politics of welfare in the UK. Political Geography. 28: $436-444$

Raco M (2013a) Neoliberal Urban Policy, Aspirational Citizenship and the Uses of Cultural Distinction in Contradictions of Neoliberal Planning. Cities, Policies and Politics. Tasan-Kok T and Baeten G (eds) London: Springer.

Rowlands R and Gurney C (2000) Young People's Perceptions of Housing Tenure. Housing Theory and Society 17(3): 121 -130.

Savage M (2005) Working-Class Identities in the 1960s: Revisiting the Affluent Worker Study Sociology 39(5): 929-946

Savage M (2015) Social Class in the 21st Century. London: Pelican.

Savage M, Watt P, and Arber S (1990) The Consumption Sector Debate and Housing Mobility. Sociology 24(1): 97-117

Savage M and Bennett T (2005) Editors' introduction: Cultural capital and social inequality. The British Journal of Sociology 56(1): 1-12

Savage M, Wardw A and Devine F (2005) Capitals, assets, and resources: some critical issues. The British Journal of Sociology 56(1): 31-47 
Savage M et al (2013) A New Model of Social Class? Findings from the BBC's Great British Class Survey Experiment Sociology 47(2): 219-250

Sayer A (2015) Why We Can't Afford the Rich. Bristol: Policy Press

Silver H (Ed) (1973) Equal Opportunities in Education. London: Methuen.

Taylor C (2001) The Geography of choice and diversity in the 'new' secondary education market of England. Area 33(1): 368 - 81

Townsend T (2006) From Inner City to Inner Suburb? Addressing Housing Aspirations in Low Demand Areas in Newcastle Gateshead, UK. Housing Studies 2(4): 501-521

Wacquant $L$ (2012) 'Three Steps Towards an Anthropology of Actually Existing Neoliberalism' Social Anthropology 19(4): 66 - 79

Watt P (2005) Housing histories and fragmented middle-class careers: the case of marginal professionals in London council housing. Housing Studies 20(3): 359-381

\section{Author Biographies}

Joe Crawford, University of St Andrews

Before entering the field of academia, Joe worked as practitioner for Shelter in Glasgow for 10 years. He took up a teaching post at the University of Stirling's Housing Policy and Practice Unit in 2008 where he also undertook a PhD looking at eviction practices in the social rented housing sector. Joe joined the Centre for Housing Research in 2015 as a qualitative researcher.

Kim McKee, University of St Andrews

Kim McKee is a Senior Lecturer and Director of the Centre for Housing Research, University of St Andrews. Her work centres on housing inequalities, combining an interest in social theory with processes of policy and governance. Kim is Managing Editor of the journal of Housing Studies, and past Chair of the Housing Studies Association (UK Learned Society). 